\title{
Analysis of the technical efficiency of yam cultivation (Dioscorea spp.) in the Caribbean Region of Colombia
}

\author{
Análisis de la eficiencia técnica del cultivo de ñame \\ (Dioscorea spp.) en la Región Caribe de Colombia
}
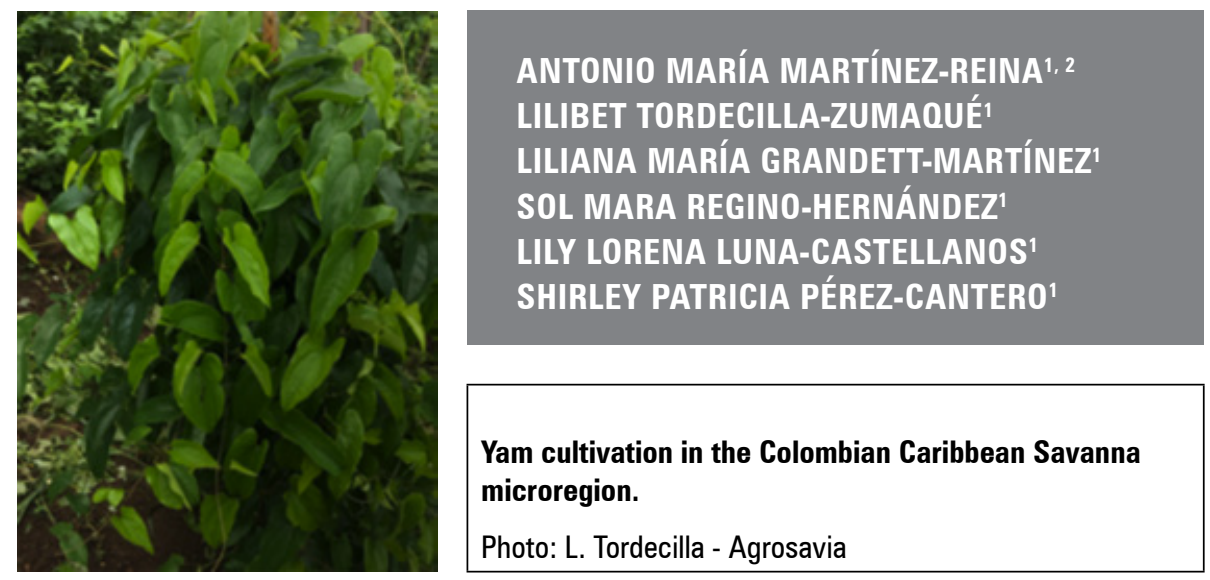

\section{ABSTRACT}

The objective was to analyze the technical efficiency of yam cultivation in producing areas of the Caribbean Region. The data were obtained through 98 structured surveys applied to experienced farmers, which included socioeconomic information such as: age, schooling, size of the cultivated area, physical crop yields, and production destination. The sampling technique was simple and applied at random. The data were analyzed in the SPSS program, and techniques such as descriptive statistics and measures of central tendency were used. Likewise, a Cobb-Douglas type econometric model was designed that allowed formulation of a production function and estimation of the parameter values. The results showed that the production efficiency was low because of underutilization of some factors, such as labor, which is 78 wages on average, excessive for the cultivation of one hectare of yams; in addition, fertilizers are used without a soil analysis and without considering the nutritional requirements of the crop. The seed is an important factor that contributes to increases in production with a coefficient of 0.033881 , so, if its quality is improved, efficiency can be increased. Experience and schooling contributed the most to the efficiency of the yam cultivation. Farmers can increase productivity with a better use of resources.

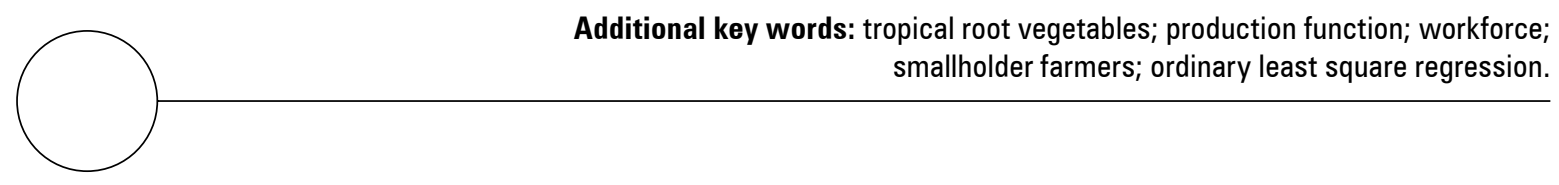

\footnotetext{
1 Corporación Colombiana de Investigación Agropecuaria (Agrosavia), Centro de Investigación Turipaná, Cerete (Colombia). ORCID Martínez-Reina, A.M.:0000-0002-9312-842X; ORCID Tordecilla-Zumaqué, L.: 0000-0003-0263-6427; ORCID Grandett-Martínez, L.M.: 0000-0002-9755-2017; ORCID Regino-Hernández, S.M.: 0000-0002-9325-7336; ORCID Luna-Castellanos, L.L.: 0000-0003-2172-7842; ORCID Pérez-Cantero, S.P.: 0000-0001-5260-0321

2 Corresponding author. amartinezr@agrosavia.co
} 


\section{RESUMEN}

El objetivo del trabajo fue analizar la eficiencia técnica del cultivo de ñame en zonas productoras de la Región Caribe. Los datos se obtuvieron mediante 98 encuestas estructuradas aplicadas a los agricultores con experiencia las cuales incluyeron información socioeconómica como: edad, escolaridad, tamaño del área cultivada, rendimientos físicos del cultivo y destino de la producción. La técnica de muestreo fue aleatorio simple aplicado al azar. Los datos fueron analizados en el programa SPSS y se utilizaron técnicas como estadísticas descriptivas y medidas de tendencia central. Igualmente se diseñó un modelo econométrico tipo Cobb-Douglas que permito formular una función de producción y estimar el valor de los parámetros. Los resultados muestran que la eficiencia en la producción es baja debido a que subutilizan algunos factores como la mano de obra la cual es de 78 jornales en promedio que resultan excesivos para cultivar una hectárea de ñame; además, usan fertilizante sin análisis de suelos y sin tener en cuenta los requerimientos nutricionales del cultivo, la semilla como factor importante contribuye al aumento de la producción con un coeficiente de 0,033881 que significa que si se mejora su calidad se puede aumentar la eficiencia. La experiencia y la escolaridad son los elementos que más contribuyen con la eficiencia del cultivo del ñame. Se concluye que los agricultores pueden aumentar su productividad con un mejor uso de los recursos.

Palabras clave adicionales: hortalizas de raíz tropicales, función de producción; fuerza laboral; pequeños productores; regresión de mínimos cuadrados ordinarios.

Received: 03-02-2021 Accepted: 20-04-202 Published: 30-04-2021

INTRODUCTION

Yam is a tropical plant of African and Asian origin, is monocotyledonous, is in the Dioscoreaceae family, and has a reserve organ that is a tuber. It has six genera, including Dioscorea, which is the most important with 600 identified species although only 12 species are edible (Coursey 1967, cited by Thurston, 1989). The characteristics change according to the variety. Those in the Dioscorea genus are generally dioecious (Santos and Macêdo, 2002). The plant appears as a vine, with aerial tubers called bulblets and underground tubers (Hata et al., 2003). The latter are the useful part and are used for consumption and propagation of new crops (Cabrera et al., 2008).

According to the FAO (2021), in 2018, the African continent was the largest producer worldwide, with close to $97 \%$ of production (70.9 million tons). In contrast, the Americas represented $2.0 \%$ of global production (1.4 million tons) (Vargas, 2019). Colombia, according to Agronet (2019), had an area of 27,099 ha in 2018, with a production of $315,434 \mathrm{t}$ and an average yield of $9 \mathrm{t} \mathrm{ha}^{-1}$. The Caribbean region provided $96 \%$ of the yam cultivated area. According to Reina (2012), Colombia had the highest yield rate in the world for yam cultivation, as well as the production characteristics: seed quality, planting type, soil type, and varieties or clones but current statistics show low production.

According to Farrell (1957), agricultural success is achieved when maximum production is achieved through the best combination of inputs or elements. Technical efficiency is defined as a strategy that guarantees that an organization or productive unit obtains maximum levels of production by using fewer physical units of each input without compromising the quality of the product. In this case, it is proposed that yam production will be more efficient with greater amounts of yams in a productive unit, with a smaller number of inputs. Economic efficiency studies evaluate whether producers carry out activities in the best possible way, making the most of the resources available to them (De los Ríos, 2006).

The Cobb Douglas production function has been used in other studies to determine the technical efficiency of agricultural production (Martínez, 2002; Bakhsh et al., 2006; Erhabor and Emokaro, 2007; 2008). It shows the relationships of a product and the variations of the inputs, demonstrating the contribution of each input and was presented as statistical evidence by Charles Cobb and Paul Douglas 
in 1928. The empirical evidence of the theory of production through the Cobb Douglas function determines the contributions of each factor of production and approaching the production frontier, the economies of scale and efficiency understood as the result of the rational use of production factors.

For this reason, this paper aimed to analyze the efficiency of yam production in the Caribbean Region of Colombia, determine the elements that could increase it, and reveal whether yam production is technically efficient and which elements explain this situation.

The African continent leads yam production and the investigation of technical efficiency in yam, it should be noted that in Colombia the presence of these studies was not evidenced and that is why the works from Africa are taken as a reference for this work. For example, Orewa and Izekor (2012) analyzed the efficiency of yam production in the State of Edo in Nigeria and produced a model that can be replicated to evaluate different production systems. Aliyu and Shelleng (2019) also analyzed the technical efficiency and economic efficiency of yam producers. They used the Envelopment Analysis of DEA data results and showed that $57 \%$ of farmers had a technical efficiency of 0.81 and more, while $43 \%$ operated with an efficiency level lower than 0.81 . The mean technical efficiency of the 100 farmers sampled in the study area was 0.78 . The farmer with the best practices had an efficiency of 1.00 , while 0.37 was the lowest. In terms of economic efficiency, the efficient producer saved about $5 \%$ of production costs.

This study aimed to demonstrate the empirical evidence of the theory of production with the Cobb Douglas function, which determines the contribution of each production factor and approaches the production frontier; the economies of scale and efficiency are understood as the result of the rational use of production factors.

Orewa and Izekor (2012) showed that the production inputs that could increase yam production include expansion of farmland, increased use of yams, fertilizers, and labor. The educational level of the respondents, the size of the household and the agricultural experience were the socioeconomic characteristics that had a significant and negative effect on the technical inefficiency of the farmers.

In the case of yams in the Caribbean Region, this evaluation looked at the extent using more land to expand production in fiscal units could lead to an efficient process, as well as some inputs such as fertilizer and labor. This study specifically sought to estimate the technical efficiency of yam producers in the producing areas of the Caribbean Region and the factors that determine the production efficiency levels.

This article introduces the topic highlighting statistical data on yam production in the world, in Latin America and in Colombia and then shows the theoretical model and the mathematical model of the Cobb Douglas function. The results of the estimates, the calculations of technical efficiency, and the ideas are presented as conclusions resulting from the discussion of the data and comparison with other studies carried out in other places in the yam production system for technical efficiency.

\section{MATERIALS AND METHODS}

The study area was in the Caribbean region in the Sabanas microregions, the coastal zone of Cordoba, and Montes de Maria (Colombia). The Colombian Caribbean is located between $12^{\circ} 60^{\prime}$ and $7^{\circ} 80^{\prime} \mathrm{N}$ and $75^{\circ}$ and $71^{\circ} \mathrm{W}$. It has an area of $536,574 \mathrm{~km}^{2}$. The average temperature is close to $25^{\circ} \mathrm{C}$. Throughout the different months of the year, with a maximum of $30^{\circ} \mathrm{C}$ in summer and a minimum of 22 or $23^{\circ} \mathrm{C}$ in winter. The climate is quite humid, with relative humidity that fluctuates between 77 and $82.5 \%$. Rains in the Departments of Cordoba, Bolivar, and Sucre, in northern Antioquia, and in the Sierra Nevada de Santa Marta continue to be frequent and abundant, on average above $1,380 \mathrm{~mm} /$ year (IDEAM, 2021).

This article analyzed the technical efficiency of yam cultivation in the producing regions of the region such as: The Savannah Region of Cordoba, Sucre and Bolivar, the Coastal Region of Cordoba, and the Montes de Maria. The data were obtained with a survey applied to 98 farmers and were used to formulate a stochastic frontier econometric model with an estimation using the Cobb Douglas ordinary least squares method.

The distribution of the municipalities was done taking into account the main producing areas of the crop in the different departments of the Caribbean region (DANE, 2018), such as: Cordoba (Chinu, Cienaga de Oro, Lorica, Los Cordobas, Moñitos, Planeta Rica, Pueblo Nuevo, Puerto Escondido and Sahagun), Sucre (Chalan, Sam After, San Onofre and Toluviejo), 
Bolivar (Carmen de Bolivar, Maria La Baja, San Jacinto and San Juan de Nepomuceno) and Antioquia (Necocli, San Juan de Uraba and Turbo), for a total of 98 producers.

To determine the sample size, simple random sampling was used for small samples according to Rodríguez (2005). It was based on a universe of 15,398 yam farmers throughout the Caribbean Region, as reported in the official statistics of agricultural evaluations and Agronet (2018). The size of the productive unit was used as a sampling variable, and it was determined that $60 \%$ of the producers cultivate less than 2 ha and that $40 \%$ cultivate more than 2 ha. The simple random sampling equation for small samples was applied:

$$
n=\frac{Z^{2} \times p \times q \times N}{\left[\left(e^{2} \times(N-1)\right)+Z^{2} \times p \times q\right]}
$$

where, $Z$ was the confidence level chosen in this case, $95 \%$; $p$ was the proportion of the population that contained the sample variable of farmers with more than 2 ha: $60 \%$; $q$ was the difference between the total population and the proportion of the population that did not meet the characteristic (in this case yams destined for the market) farmers with areas greater than 2 ha, and $e$ was the maximum error allowed in the case of $10 \%$ n population size.

For this case, the variables in the equation were: $N$, total population, in this case 15,398 yam-producing farmers in the four departments; $Z$, the chosen level of confidence, 95\% (1.96); $p$, proportion of farmers with units larger than 2 ha, 60\%, 6,159 in total; and $q$, difference between the total population and the number of farmers with productive units less than 2 ha, 9,239 in total.

92 randomly distributed surveys were used in the area where yams are grown in the four departments of the study area, as shown in table 1.

\section{Table 1. Survey distribution by proportional allocation of the yam Caribbean Region, 2019.}

\begin{tabular}{|l|c|c|c|}
\hline Departament & Productive units & Percentage & Surveys \\
\hline Bolivar & 5.558 & 36 & 33 \\
\hline Cordoba & 7.164 & 47 & 43 \\
\hline Sucre & 1.579 & 10 & 10 \\
\hline Antioquia & 1.097 & 7 & 6 \\
\hline Total & 15.398 & 100 & 92 \\
\hline
\end{tabular}

Source: Calculations with statistical base, Secretariats of Economic Development The Caribbean Region, 2019.
The data on the number of productive units were obtained from the statistics of the agricultural sector available in the secretariat of economic and agro-industrial development in the yam producing departments, which were related to the data from the DANE (2018).

The information and field data were obtained from a structured survey applied to 98 farmers, composed of 40 variables and 70 questions made up of two blocks of questions. One block was a socioeconomic component (land tenure, experience as a producer, road infrastructure, land topography, family composition, educational level, family sources of income, economic), and the other was for technical activity (planting times, seeds, soil management, water management, pests, diseases, weeds, harvest management, postharvest and sale of the product), The data files were elaborated to feed the model that measured the technical efficiency of the yam production. For the analysis of the survey, descriptive statistics such as frequency distribution were used, in addition to the formulation of the econometric model to estimate the parameters and determine the production gaps.

It should be clarified that the analysis of the technical efficiency of a production system can be done in two ways: one, with the use of DEA (Data Envelopment Analysis) through linear programming techniques, or two, using the stochastic frontier with econometric techniques. Empirical studies, such as that of Rodríguez et al. (2017), have shown that there are no reasons to use one or the other method, and this choice is left to the discretion of the researcher. Here, the stochastic frontier was used with estimates using the Ordinary Least Squares method, which is widely known in empirical research with econometric models such as the one used in this study with the Cobb Douglas function.

The technical efficiency of yam producers in the study area was analyzed with the Cobb-Douglas functional form production function.

The general form of this function was:

$Y=F(k, L)=A k^{\infty} / x^{\beta}$

where, $y$ was total yam production expressed in physical units; $k$ was capital factor $1 ; L$ was work; $\alpha$ was change in $Y$ when capital factor changes; and $\beta$ was change in $Y$ when the labor factor changes.

In other words, the change that occurs in production when the units of capital and labor change or the 
response of production to changes in the use of the factor's capital and labor. This is a general way of presenting the function in the model they disaggregate the factors of production.

The proposed model of the production function to measure the technical efficiency of yams was:

The general form of the Cobb Douglas function was:

$Y=F(k, L)$

where, $Y$ was total production; $K$ was units of capital factor, and $L$ was units of work factor.

The form of the production function model with the factors in natural logarithm was:

$y=\beta_{0}+\beta_{1} \ln x_{1}+\beta_{2} 1 \mathrm{n} x_{2}+\beta_{3} \ln x_{3}+\beta_{4} \ln x_{4}+\varepsilon_{1}$

where, In was natural logarithm; $Y$ was total yam production expressed in physical units $(\mathrm{kg}) ; X_{1}$ was yield $\mathrm{kg} \mathrm{ha}{ }^{-1} ; X_{2}$ was labor wages/ha; $X_{3}$ was seed amount of seed used/ha; $X_{4}$ was fertilizer $\mathrm{kg} \mathrm{ha}^{-1} ; b_{0}-b_{4}$ were parameters to be estimated (regression coefficients); $\varepsilon_{\mathrm{i}}$ was compound error term defined as $V_{\mathrm{i}}-U_{\mathrm{i}}$, and $V_{\mathrm{i}}=$ Random variables were assumed independent of $U_{\mathrm{i}}$, identical and normally distributed with zero mean and constant variance $N\left(0, \mathrm{~Sv}_{2}\right)$.

In the case of inefficiency, factors that negatively affect the efficiency of yam production and have more to do with socioeconomic characteristics such as age, schooling, and experience were considered, according to Orewa and Izekor (2012).

$y=\alpha_{0}+\alpha_{1} 1 \mathrm{n} x_{1}+\alpha_{2} \ln x_{2}+\alpha_{3} \ln x_{3}+\alpha_{4} \ln x_{4}+\varepsilon_{1}$

where, $y$ was technical inefficiency; $\alpha_{1}$ was age (years); $\alpha_{2}$ was educational level (years); $\alpha_{3}$ was agricultural experience (years); $\alpha_{4}$ was area cultivated in yams in hectares; $\varepsilon_{\mathrm{i}}=$ error term, and $\alpha_{0}-\alpha_{3}$ were parameters to be estimated.

The estimation was made with the ordinary least squares method in Eviews v. 8. The original data from the field surveys of expert farmers in yam cultivation in the Caribbean producing regions of Colombia were organized in flat files of Excel for the calculations, graphical analysis and other tools that allow the analysis. They were then transformed into logarithms to measure the elasticity of production in relation to each of the independent variables or to the increase in production factors and the response in yam production, the model was run, inference tests statistics and information analysis.

The technical efficiency was calculated by relating the real yam production obtained in each of the productive units with the potential production, that is, the production frontier.

$$
E T=\frac{\text { Real production }}{\text { Potential production }}
$$

In this case, the natural logarithm of the economies of scale was used, calculated by multiplying the averages of each variable with the standard deviation, arriving at the economies of scale. For potential production, the initial Eq. (6) was replaced with the estimated parameters of each variable, giving the production frontier.

\section{RESULTS AND DISCUSSION}

\section{Socioeconomic characteristics of the respondents}

Table 2 presents some of the socioeconomic characteristics of the farmers according to the survey applied in the yam-producing areas of the Caribbean region.

According to table 2, yam production in the Caribbean region is carried out in a greater proportion by men who make the decisions to cultivate and the techniques used. Something similar was found in a study by Ekunwe and Orewa (2007), who found that 98.6\% of yam producers in Kogi were men. This author and the production of yam in Africa were taken as a reference for finding similar conditions in terms of the organization of production and producer type because Colombia yam species do not have studies on the technical efficiency.

For services, water and electricity predominated in the entire sample; however, more than $90 \%$ of those surveyed had cell phones.

It was observed that the yam producers had an advanced age with few young people, with an average age of 57 years, which indicated that the future will see less yam production. This implies that the farmers in the study area were aging. Similar results were found in the study by Orewa and Izekor (2012), 
where the majority $(55.0 \%)$ of the respondents were within the age group of 50 to 59 years. The ages of the sampled farmers ranged from 35 to 65 years, with an average age of 51 years.

Table 2. Socioeconomic characteristics of farmers who grow yams in the Caribbean Region.

\begin{tabular}{|c|c|}
\hline Characteristics & \multirow{2}{*}{ Frequencies } \\
\hline Gender & \\
\hline Male & 93 \\
\hline Female & 4 \\
\hline \multicolumn{2}{|l|}{ Education } \\
\hline None & 6 \\
\hline Primary & 21 \\
\hline High school & 42 \\
\hline Technical & 15 \\
\hline Professional & 8 \\
\hline Postgraduate & 1 \\
\hline \multicolumn{2}{|l|}{ Services } \\
\hline Water & 6 \\
\hline Electricity & 8 \\
\hline Water, electricity, sewage and propane gas & 35 \\
\hline Water, electricity, mobile phone & 30 \\
\hline Mobile phone, water, propane gas & 18 \\
\hline \multicolumn{2}{|l|}{ Age } \\
\hline Minimum $=27$ years & 1 \\
\hline $\begin{array}{l}\text { Maximum }=81 \text { years } \\
\text { Average }=57 \text { years }\end{array}$ & 53 \\
\hline Standard deviation $=13$ & 46 \\
\hline \multicolumn{2}{|l|}{ Experiences } \\
\hline Mínimun > 1 year & 2 \\
\hline Maximun = 70 years & 50 \\
\hline $\begin{array}{l}\text { Average }=25 \text { years } \\
\text { Standard deviation }=15.2\end{array}$ & 45 \\
\hline
\end{tabular}

Source: Surveys to 97 producers, Agrosavia 2019.
The predominant type of tenure was ownership in $40 \%$ of the sample; the average area devoted to this crop was 1.3 ha, and the mode was 1.0 ha.

Experience was important, which on average was 25 years, guaranteeing security in production and confidence in the information provided in the survey. In the Caribbean Region, experience was greater than in the findings of Orewa and Izekor (2012), where 31\% of the respondents had an agricultural experience of 5 to 10 years, and $28.89 \%$ had between 11 and 15 years of experience. Similarly, a study by Oluwatusin (2011) reported 14-year experience in the cultivation of yams in the State of Osun in Nigeria.

The results of the regression with the least squares method and the estimation of parameters can be seen in table 3 .

The results of the least squares estimation of the production function in table 3 are interpreted as follows: the value of the intercept, -24.66196 , indicates that, with this yam production per hectare with the inputs used, there was inefficiency, and the $\alpha$ value of the function and the estimated parameters were the $\beta$ values, there will be as many values as explanatory variables and this value indicates that keeping the other variables constant and varying one in particular, the quantity produced changes. However, an increase of one factor does not always cause increases in production in the same proportion, so the sum of the coefficients $\beta$ s generated a result less than 1, which indicated decreasing returns to scale.

Yam production is determined by the yield expressed in kilograms per hectare, and the higher the yield, the higher production is expected to be. The positive coefficient of 0.0335867 meant that an increase in $1 \%$ of the yield saw production increased by $3 \%$.

Table 3. Results of the regression model Cobb Douglas yam Caribbean Region, 2020.

\begin{tabular}{|l|c|c|c|c|}
\hline Variable & Coefficient & Standard error & Statistical t & Probability, P value \\
\hline C & -24.66196 & 1.217744 & -20.25217 & 0.0000 \\
\hline Yield & 0.0335867 & 0.061149 & 0.586550 & 0.5590 \\
\hline Labor & -0.85319 & 0.080946 & -10.07237 & 0.0000 \\
\hline Seed & 0.033881 & 0.090412 & 0.374736 & 0.7087 \\
\hline Fertilization & -0195797 & 0.077759 & -2.518011 & 0.0135 \\
\hline Cost & 1.846620 & 0.086735 & 21.29035 & 0.0000 \\
\hline
\end{tabular}

Source: Calculations based on Agrosavia 2019 fieldwork. 
Labor, with a coefficient of -0.85319 , meant that labor was underutilized; 78 wages are excessive to cultivate 1 ha of yams. The seed, with a coefficient of 0.033881 , indicated that it is a necessary factor, and that, if its use is improved, more quantities of yams could be produced. Fertilization, with a coefficient of -0.195797 , meant that fertilizer is being used in an irrational way, so the reaction is opposite, one could think about doing soil analysis and supplying according to the requirements of the crop and the edaphic demand. Finally, the cost of inputs such as herbicides and other production elements, with a coefficient of 1.846620 , indicated that elements must be incurred that would generate an additional cost, such as soil analysis, but that would increase production. Under production conditions, maximum efficiency was not reached, with underutilization of some factors such as labor and fertilization.

When comparing the results found in the Caribbean Region of Colombia, there was some coincidence with those of Shehu et al. (2010) in the case of yam production in the State of Benue Nigeria, where the seed was a basic factor that determined the increase in yam production and was closely related to the study by Orewa and Izekor (2012) on the variables labor and fertilizer.

The results for the measurement of the technical efficiency of yams in the Caribbean Region differ to some extent from those of Orewa and Izekor (2012), who worked in the State of Edo in Nigeria for farm size, with a coefficient of 0.495 , the yield had 0.540 , the fertilizer had 0.040, and the labor had 0.367, which was positive and statistically significant. The cultivated area should be increased with an expected increase in fertilizer and labor, so productivity can be increased.

The results showed that the technical efficiency was 0.77 , which indicates that production was inefficient because, for there to be no technological gap, this value must be equal to 1 . Also, according to the sum of the elasticities of the variables in relation to production, there were decreasing returns to scale with a value of 0.90 . This means that, although there was productivity in the cultivation of yams, the inputs were not used properly, as in the case of labor and fertilizers. On the other hand, efforts should be made to improve the seed component, which is the basis of the entire production process. These results compared with what was found by Orewa and Izekor (2012) with a technical efficiency of 0.69 , however for this study with the average yields only a technical efficiency of 0.31 is reached, with a margin of 0.69 for improvement.

In the yam production system in the Caribbean Region and in view of the scope of this work, despite its degree of adaptation, the yields were low, on average $7.8 \mathrm{t} \mathrm{ha}^{-1}$, with a minimum of $2 \mathrm{t} \mathrm{ha} \mathrm{H}^{-1}$. This was due in part to poor management practices such as seed treatment, which, despite the existence of technologies, had very low adoption. The same happens with varieties that are grown and new varieties with resistance to diseases, but many producers do not use them. Obtaining production with higher yields would have repercussions on food security as this product is consumed daily by the population of the Caribbean Region, as evidenced in the present investigation.

\section{Determinants of technical inefficiency}

The inefficiency was studied considering the socioeconomic characteristics of the farmers that were described at the beginning of the results. The results of the estimation with the Ordinary Least Squares are presented in table 4.

Table 4 presents the relative efficiency levels, showing which variables caused inefficiency under these

Table 4. Regression results for measuring the inefficiency of the yam production system Caribbean Region, 2020.

\begin{tabular}{|l|c|c|c|c|}
\hline Variable & Coefficient & Standard error & Statistical t & Probability, P value \\
\hline C & 3.200428 & 1.677 .481 & 1.907883 & 0.0595 \\
\hline Age & -0.741254 & 0.447519 & -1.656362 & 0.1011 \\
\hline Education & -0.352789 & 0.268630 & -1.313293 & 0.1924 \\
\hline Experience & 0.566239 & 0.142375 & 3.977104 & 0.0001 \\
\hline Area in yam & 0.961213 & 0.133686 & 7.190101 & 0.0000 \\
\hline
\end{tabular}

Source: Calculations based on Agrosavia 2019 fieldwork. 
conditions. The negative sign of the parameter indicates that the variable positively influenced the efficiency of production; under these conditions, the age coefficient $(-0.741254)$ indicated that the older the farmers are, the more knowledgeable about the crop they have, and they can achieve better results in production than young farmers.

Similarly for education (-0.3352789), farmers with more years of education tend to be more technically efficient in yam production, perhaps because they are less reluctant to change and to accept new knowledge; in this case, less years of study meant less efficiency in cultivation.

These results coincide with similar reports by Pius and Odjuvwuederhie (2006), Ekunwe et al. (2008), Ojo et al. (2009), Shehu et al. (2010) and Oluwatusin (2011), where more years of education increased the probability of adopting efficient technologies that tended to increase; the same conclusion was reached by Martínez and Gómez (2012) in a study on the adoption of soil technologies for cotton in the Upper Magdalena Warm Valley.

Experience in cultivation had a parameter value of 0.566239 with respect to efficiency; it can be inferred that more years cultivating yams meant lower efficiency, perhaps because they are reluctant to change and have difficulty modifying the use of inputs. Contrary results were found in the works of Izekor (2012), who showed that the more they experiment, the less inefficiency yam cultivation has in Edo Nigeria. Other results, such as that of Oluwatusin (2011), for yam producers in the State of Osun in Nigeria indicated that, with more years of experience, producers become more specialized.

The area dedicated to the cultivation of yams with a parameter value of 0.961213 indicated that it is not necessarily possible to increase efficiency with greater cultivated area. Here, this applies the principle of productivity to produce more using the same quantities of the factor or to produce the same units of product but spending less. With the same surface, it is possible to obtain greater kilos of yams per hectare.

When interrelating the socioeconomic variables with the techniques for understanding the efficiency of yam cultivation in the Caribbean Region of Colombia, it was observed that there was underutilization of some resources, such as labor, that uses the greatest amount of wages for the nine months of productive cycle. This could be improved if periodic weed controls are carried out in the early phenological stages of the crop. On the other hand, fertilization had effects contrary to what was expected, as explained by the lack of soil analysis and the lack of knowledge of the nutritional requirements of the crop.

The empirical result of the model estimated with ordinary least squares showed that production was inefficient and that there were technological gaps. In the first place, the presence of decreasing returns to scale was evidenced, expressed in the summary of the value of the regression coefficients with a value of $0.9=\beta$ and $\alpha$ values of 0.1 ; for increasing returns, they must be greater than 1. 1- $\alpha$ represents the inefficiency of production, which is only overcome with yields of $25 \mathrm{t} \mathrm{ha}^{-1}$. It is noted that these results are the product of field work with uncontrolled research, so the results are not conclusive but can be used as a reference for production decisions.

\section{CONCLUSIONS}

Even though farmers present some rationality in the allocation of resources, technical efficiency was not fully achieved (0.77), as evidenced in the underutilization of some production factors such as labor and fertilizers. The number of wages was excessive, and the fertilization was carried out without technical criteria that lead to inefficiency in the production process.

The technical inefficiency in yam production with wide production gaps was demonstrated with an average yield of $10 \mathrm{t} \mathrm{ha}^{-1}$, a production gap of 0.60 , and a technical efficiency of 0.396 , far from optimal production, calculated as $25 \mathrm{t} \mathrm{ha}^{-1}$. Even though the return indicators with current production showed positive net income, the underutilization of resources and the presence of production gaps were evident.

In yam production, the seed is an important input as the basis of all activity. It could be seen that rational management is carried out because it contributes positively to production; however, this participation in efficiency can be increased when new seed production and storage techniques are incorporated.

Within the socioeconomic characteristics of the producers, schooling and experience in cultivation stood out. These two elements are key to fighting inefficiency since it was intended to prove and identify, 
in this direction the experience of farmers should be taken advantage of and combined with the level of education inasmuch as greater receptivity would be achieved, higher levels of adoption and therefore technical efficiency would increase.

Conflict of interests: The manuscript was prepared and reviewed with the participation of the authors, who declare that there exists no conflict of interest that puts at risk the validity of the presented results.

\section{BIBLIOGRAPHIC REFERENCES}

Agronet. 2019. Área cosechada, producción y rendimiento de ñame. In: https://www.agronet.gov.co/estadistica/ Paginas/home.aspx?.cod=1; consulted: April, 2021.

Aliyu, A. and A.B. Shelleng. 2019. Analysis of technical, allocative and economic efficiencies of yam producers in Ganye local government area of Adamawa state, Nigeria. Int. J. Eng. Technol. Manage. Res. 6(7), 129143. Doi: 10.29121/ijetmr.v6.i7.2019.426

Bakhsh, K., B. Ahmad, and S. Hassan. 2006. Food security through increasing technical efficiency. Asian J. Plant Sci. 5(6), 970-976. Doi: 10.3923/ajps.2006.970.976

Cabrera, J., R. Gómez, A. Rayas, M. DeFeria, J. López, M. Basail, and V. Medero. 2008. Protocolo para la formación de microtubérculos de ñame (Dioscorea alata L.) en sistema de inmersión temporal. Rev. Colomb. Biotecnol. 11(2), 19-30.

DANE, Departamento Administrativo Nacional de Estadística of Colombia. 2018. Encuesta Nacional Agropecuaria. Bogota.

De los Ríos, C. 2006. La eficiencia técnica en la agricultura peruana. El caso del algodón Tangüis en los valles de Huaral, Cañete y Chincha. Debate Agrario (40-41), 141-168.

Erhabor, P.O. and C.O. Emokaro. 2007. Relative technical efficiency of cassava farmers in the three agroecological zones of Edo state, Nigeria. J. Appl. Sci. 7(19), 2818-2823. Doi: 10.3923/jas.2007.2818.2823

Ekunwe, P.A. and S.I. Orewa. 2007. Technical efficiency and productivity of yam in Kogi State, Nigeria. J. Appl. Sci. 7(13), 1818-1820. Doi: 10.3923/jas.2007.1818.1820

Ekunwe, P.A., S.I. Orewa, and C.O. Emokaro. 2008. Resource use efficiency in yam production in Delta and Kogi State, Nigeria. Asian J. Agric. Res. 2(2), 61-69. Doi: 10.3923/ajar.2008.61.69

FAO. 2021. FAOSTAT - Food and agriculture data. In: http://www.fao.org/faostat/en/\#home; consulted: April, 2021.

Farrell, M.J. 1957. The measurement of production efficiency. J. R. Stat. Soc. Ser. A 120(3), 253-290. Doi: $10.2307 / 2343100$
Hata, Y., M.T. Reguero, L. Arteaga de García, G. Buitrago, and A. Alvarez. 2003. Evaluación del contenido de sapogeninas en variedades nativas de ñame (Dioscorea spp.) provenientes de la colección de la Universidad de Córdoba. Rev. Colomb. Cienc. Quím. Farm. 32(2), 149-157.

IDEAM, Instituto de Hidrología, Meteorología y Estudios Ambientales of Colombia. 2018. Boletín Agroclimático Nacional: Julio, edición 43. In: http://www.ideam. gov.co/documents/21021/66701198/Bolet\%C3\%Ad$\mathrm{n}+$ Agroclim\%C3\%A1tico + Nacional + No $+43+\mathrm{Ju}-$ lio+de+2018.pdf; consulted: April, 2021.

Martínez, A. 2002. Aplicación de la función Cobb Douglas al secado de yuca en la Costa Atlántica de Colombia. Comercio Exterior 54(11), 970-974.

Martínez, A. and J. Gómez. 2012. Elección de los agricultores en la adopción de tecnologías de manejo de suelos en el sistema de producción de algodón y sus cultivos de rotación en el valle cálido del Alto Magdalena. Corpoica Cienc. Tecnol. Agropecu. 13(1), 62-70. Doi: 10.21930/rcta.vol13_num1_art:241

Ojo, M.A., U.S. Mohammed, A.O. Ojo, and R.S. Olaleye. 2009. Return to scale and determinants of farm level technical inefficiency among small scale yam based farmers in niger state, nigeria: implication for food security. Int. J. Agric. Econ. Rural Dev. 2(1), 43-51.

Oluwatusin, F.M. 2011. Measuring technical efficiency of yam farmers in Nigeria: a stochastic parametric approach. Agric. J. 6(2), 40-46. Doi: 10.3923/ aj.2011.40.46

Orewa, S. and O. Izekor. 2012 Technical efficiency analysis of yam production in Edo state: A stochastic frontier approach. Int. J. Dev. Sustain. 1(2), 516-526.

Pius, CI. and E.I. Odjuvwederhie. 2006. Determination of yam production and economic efficiency among smallholder farmers in Southeastern, Nigeria. J. Central Eur. Agric. 7(2), 337-342.

Reina, Y. 2012. El cultivo de ñame en el Caribe colombiano. Serie Documentos de Trabajo Sobre Economía Regional 168. Banco de la Republica - Centro de Estudios Económicos Regionales, Cartagena, Colombia. pp. 12-21.

Rodríguez, J. 2005. Métodos de muestreos, casos prácticos. Centro de Investigaciones Sociológicas, Madrid.

Rodríguez, R., M. Pía, and E. Raña. 2017. Eficiencia técnica en la agricultura familiar: Análisis envolvente de datos (DEA) versus aproximación de fronteras estocásticas (SFA). Nova Sci. 9(1), 342-370. Doi: 10.21640/ ns.v9i18.697

Santos, E.S. and L.S. Macêdo. 2002. Tendências e pespectivas da cultura do inhame (Dioscorea sp.) no Nordeste do Brasil. pp. 21-31. In: Proc. II Simpósio Nacional sobre as Culturas do Inhame e do Taro. Anais. Emepa-PB, João Pessoa, Brazil.

Shehu, J.F., J.T. Iyortyer, S.I. Mshelia, and A.A.U. Jongur. 2010. Determinants of yam production and technical efficiency among yam farmers in 
Benue state, Nigeria. J. Social Sci. 24(2), 143-148. Doi: 10.1080/09718923.2010.11892846

Thurston, H.D. 1989. Enfermedades de cultivos en el tropico. Centro Agronómico Tropical de Investigación y Enseñanza (CATIE), Turrialba, Costa Rica.
Vargas, A. 2019. Comportamiento productivo de materiales de siembra de ñame (Dioscorea alata) en la región Huetar Norte, Costa Rica. Undergraduate thesis. Campus Tecnológico Local San Carlos, Tecnológico de Costa Rica, Santa Clara de San Carlos, Costa Rica. 